\title{
PENGGUNAAN AMPAS PATI AREN DALAM RANSUM TERHADAP KARAKTERISTIK KARKAS BABI BALI JANTAN
}

\author{
PERMANA, K. P., N. L. P. SRIYANI, DAN I K. SUMADI \\ Program Studi Magister Ilmu Peternakan \\ Fakultas Peternakan, Universitas Udayana \\ e-mail: kadekairlangga@gmail.com
}

\begin{abstract}
ABSTRAK
Tujuan dari penelitian adalah untuk mengetahui pengaruh penggunaan ampas pati aren dalam ransum terhadap karakteristik karkas babi bali jantan. Penelitian menggunakan rancangan acak lengkap (RAL) dengan empat perlakuan dan empat kali ulangan. Perlakuan yang digunakan adalah ransum tanpa ampas pati aren (A) sebagai kontrol, ransum kontrol dengan penggunaan $5 \%$ ampas pati aren (B), ransum kontrol dengan penggunaan 10\% ampas pati aren (C), ransum kontrol dengan penggunaan 15\% ampas pati aren (D). Variabel dalam penelitian ini adalah karakteristik karkas yang meliputi bobot potong, bobot karkas, panjang karkas, persentase karkas, tebal lemak punggung, luas urat daging mata rusuk (UDMR), flesing index (FI), persentase daging, tulang, dan lemak karkas. Hasil penelitian menunjukkan bahwa rataan bobot potong bobot karkas, panjang karkas, persentase karkas, tebal lemak punggung, luas UDMR dan FI tidak berbeda nyata $(\mathrm{P}>0,05)$, sedangkan untuk persentase tulang pada perlakuan D yaitu 17,26\% dan persentase lemak pada perlakuan A paling tinggi yaitu 40,22\% dan berbeda nyata $(\mathrm{P}<0,05)$. Simpulan dari penelitian adalah penggunaan ampas pati aren dari 5-15\% dalam ransum babi bali jantan tidak mempengaruhi karakteristik karkas tetapi dapat menurunkan persentase lemak pada babi bali.
\end{abstract}

Kata kunci: ampas pati aren, babi bali, karakteristik karkas

\section{THE USE OF PALM STARCH SUGAR IN RATION ON CARCASS CHARACTERISTIC OF BALI MALE PIGS}

\begin{abstract}
This study aims to find the effect of using of palm starch sugar in ration on characteristics of bali male pigs carcass. This study used a completely randomized design (CRD) with four treatments and four replications. The treatments used are ration without palm sugar starch (A) as control, control ration with the use of $5 \%$ palm sugar starch (B), control ration with the use of 10\% palm sugar starch (C), and control ration with $15 \%$ use of palm sugar starch (D). The variables observed are physical characteristics of carcass consists of: body weight, carcass weight, carcass length, carcass percentage, thicknes of back fat, loin eye area (LEA), fleshing index (FI), percentage of meat, bone and carcass fat. The results showed that weight of carcass, carcass length, carcass percentage, thickness of back fat, loin eye, fleshing index and percentage of meat were not significantly different $(P>0.05)$. Percentage of bone in treatment $\mathrm{D}$ was $17,26 \%$, and the highest fat percentage in treatment $\mathrm{A}$ was $40,22 \%$ and significant different $(\mathrm{P}<0.05)$. It can be concluded that $5-15 \%$ use of palm starch sugar in ration fed to male bali pigs not effecting the carcass characteristics but reduce the percentage of fat.
\end{abstract}

Keywords: palm starch dregs, bali pigs, characteristics of carcass

\section{PENDAHULUAN}

Ternak babi merupakan ternak monogastrik penghasil daging yang memiliki potensi besar untuk dikembangkan dalam jumlah besar dan waktu yang relatif cepat dalam rangka pemenuhan kebutuhan protein hewani karena ternak babi memiliki sifat-sifat dan kemampuan yang menguntungkan diantaranya laju pertumbuhan yang relatif cepat antara $0,5^{-0,7}$ kg per hari, beranak banyak (prolifik) yaitu 6-12 ekor sekali melahirkan dan frekwensi melahirkan anak dua kali dalam setahun, bahkan lima kali dalam dua tahun (Aritonang, 1993). Selain itu babi memiliki persentase karkas yang dapat mencapai 65\%-80\% (Siagian, 1999). 
Babi bali merupakan sumber plasma nutfah dari bali yang memiliki keunikan baik dari bentuk morfologisnya ataupun kemampuan adaptasinya terhadap pakan terutama dalam pemanfaatan limbah. Pakan merupakan biaya paling terbesar dalam usaha peternakan yaitu sekitar $65-85 \%$ dari total biaya produksi (Siagian, 1999) sehingga untuk menekan biaya yang begitu besar diperlukan pakan alternatif yang bisa menekan biaya yang begitu besar.

Salah satu pakan alternatif yang bisa digunakan adalah dengan pemanfaatan bahan pakan yang berasal dari limbah pertanian. Dengan berkembangnya usaha pertanian tanaman pangan hortikultura dan perkebunan akan menyebabkan meningkatnya ketersediaan limbah yang akan dihasilkan, salah satunya adalah limbah yang berasal dari industri pengolahan sagu dari tanaman aren (Arenga pinnata Merr) yang berupa ampas pati aren.

Limbah ini masih memiliki kandungan nutrisi yang cukup baik diantaranya bahan kering (BK) 49,69\%, bahan organik (BO) 43,66\%, protein kasar (PK) 3,69\%, serat kasar (SK) 22,98\% dan total digestible nutrient (TDN) sebesar 40,82\% (Firdayati dan Handajani, 2005) sehingga membuka kemungkinan limbah tersebut dapat dijadikan bahan alternatif campuran pakan ternak.

Selama ini, penggunaan ampas pati aren sudah sering dimanfaatkan oleh petani di pedesaan sebagai pakan ternak, terutama diberikan kepada ternak itik dan babi, akan tetapi, petani di pedesaan penggunaanya masih dengan perkiraan tanpa memperhitungkan pemberian yang tepat. Melihat kondisi tersebut, penelitian ini dilakukan karena belum adanya informasi secara ilmiah mengenai pemanfaatan ampas pati aren dalam ransum ternak babi. Oleh karena itu dilakukan penelitian mengenai penggunaan ampas pati aren dalam ransum terhadap karakteristik karkas babi bali jantan.

\section{MATERI DAN METODE}

\section{Rancangan Penelitian}

Rancangan yang digunakan dalam penelitian ini adalah rancangan acak lengkap (RAL) dengan empat perlakuan dan empat kali ulangan. Perlakuan yang diberikan sebanyak empat yaitu ransum tanpa ampas pati aren (A) sebagai kontrol, ransum kontrol dengan penggunaan $5 \%$ ampas pati aren (B), ransum kontrol dengan penggunaan 10\% ampas pati aren (C), dan ransum kontrol dengan penggunaan $15 \%$ ampas pati aren (D). Masing-masing perlakuan diulang empat kali sehingga babi yang digunakan sebanyak 16 ekor.

\section{Lokasi dan Waktu Penelitian}

Penelitian ini dilaksanakan di Banjar Sekarmukti, Desa Pangsan, Kecamatan Petang, Kabupaten Badung.
Selama tiga bulan babi dipelihara dan pada akhir penelitian dilakukan pemotongan babi. Penelitian ini dimulai dari bulan Januari sampai dengan April 2017.

\section{Ternak Penelitian}

Babi yang digunakan dalam penelitian ini adalah babi bali jantan lepas sapih dengan berat antara $\pm 10-11 \mathrm{~kg}$. Babi dibeli dari peternak babi bali di Banjar Pegending, Desa Dalung, Kecamatan Kuta Utara, Badung. Babi yang dipergunakan sebanyak 16 ekor, dipelihara dalam kandang dengan memberi perlakuan selama 3 bulan.

\section{Ampas Pati Aren}

Ampas pati aren yang digunakan dalam penelitian ini diambil di industri pengolahan tepung aren atau sagu yang berada di daerah Petang yang masih bersifat tradisional. Adapun tahapan-tahapan yang dilakukan yaitu pemotongan batang aren dibagi menjadi empat bagian secara membujur, dilanjutkan dengan memisahkan empulur dari batang, empulur yang sudah dikeluarkan, selanjutnya digiling dengan mesin parut. Hasil parutan dari mesin dikumpulkan dan dimasukkan ke dalam bak yang dialiri air, diremas-remas dan diaduk untuk memisahkan serbuk-serbuk dari serat-serat yang kasar sehingga pati keluar dan larut dalam air sehingga mengendap. Hasil sampingan dari pengolahan tersebut yang berupa ampas pati aren selanjutnya dijemur dibawah sinar matahari sampai kering matahari, setelah kering ampas pati aren siap untuk digunakan di dalam ransum penelitian.

\section{Ransum Penelitian}

Ransum yang digunakan dalam penelitian ini adalah jagung kuning, konsentrat 152, polard bogasari cap angsa, minyak sawit, mineral 10, garam dapur $(\mathrm{NaCl})$, dan ampas pati aren.

Tabel 1. Komposisi bahan penyusun ransum penelitian

\begin{tabular}{lcccc}
\hline \multirow{2}{*}{ Komposisi } & \multicolumn{4}{c}{ Perlakuan } \\
\cline { 2 - 5 } & $\mathrm{A}$ & $\mathrm{B}$ & $\mathrm{C}$ & $\mathrm{D}$ \\
\hline Jagung kuning (\%) & 41 & 38,95 & 36,90 & 34,85 \\
Konsentrat 152 (\%) & 26 & 24,70 & 23,40 & 22,10 \\
Polard (\%) & 30 & 28,50 & 27,00 & 25,50 \\
Minyak sawit (\%) & 2 & 1,90 & 1,80 & 1,70 \\
Mineral 10 & 0,50 & 0,47 & 0,45 & 0,425 \\
NaCl & 0,50 & 0,47 & 0,45 & 0,425 \\
Ampas Pati Aren & 0 & 5 & 10 & 15 \\
Jumlah & 100 & 100 & 100 & 100 \\
\hline
\end{tabular}

\section{Variabel Penelitian}

Adapun variabel yang diteliti dalam penelitian ini adalah bobot potong, bobot karkas, persentase karkas, panjang karkas, tebal lemak punggung, luas urat daging mata rusuk, fleshing index, persentase daging, tulang, dan lemak karkas. 
Tabel 2 : Kandungan nutrien ransum penelitian

\begin{tabular}{lcccc}
\hline \multicolumn{1}{c}{ Zat Nutrisi (\%) } & Kontrol (A) & B & C & D \\
\hline Gross energi (kkal/kg) & 3704 & 3675 & 3655 & 3630 \\
Protein kasar & 16,07 & 15,62 & 14,81 & 14,01 \\
Serat kasar & 7,33 & 8,10 & 9,76 & 11,42 \\
Lemak & 4,12 & 3,94 & 3,75 & 3,56 \\
Kalsium (Ca) & 1,100 & 1,096 & 1,091 & 1,085 \\
Fosfor (P) & 0,73 & 0,72 & 0,72 & 0,71 \\
\hline
\end{tabular}

Sumber: Hasil analisis laboratorium akreditasi balai penelitian ternak Ciawi, Bogor (2017)

\section{Prosedur Penelitian}

Sebelum ternak babi masuk ke dalam kandang seminggu sebelum penelitian dilakukan, kandang yang akan digunakan untuk penelitian disemprot dengan desinfektan pada seluruh bagian kandang yang bertujuan untuk membunuh bakteri patogen. Setelah melewati fase satu minggu ternak babi sudah siap untuk dimasukan ke dalam kandang. Sebelum dimasukkan ke dalam kandang ternak babi terlebih dahulu diberi vitamin dan obat cacing kemudian ditimbang dan ditaruh secara acak.

Pengacakan babi dilakukan dengan memilih 16 ekor anak babi yang selisih bobotnya tidak berbeda jauh yang digunakan sebagai sampel dalam penelitian dan setiap satu petak kandang diisi satu ekor babi sehingga terdapata 16 petak kandang. Sampel yang dipilih secara acak tersebut kemudian diletakkan dalam kandang. Ternak babi diberikan masa prelim selama seminggu untuk membuat babi terbiasa dengan ransum yang akan diberikan. Pencampuran ransum dibuat dari jumlah yang kecil sampai dengan jumlah yang terbesar dengan bahan sebagai berikut: jagung kuning, konsentrat 152, pollard, minyak sawit, mineral 10 , garam $(\mathrm{NaCl})$, dan ampas pati aren. Pemberian pakan dilakukan pada pagi dan sore hari. Air minum diberikan secara ad-libitum

Prosedur Pemotongan

Pada akhir periode penelitian selanjutnya ternak babi dipotong. Babi yang akan dipotong terlebih dahulu dipuasakan selama 12 jam. Setiap babi diberi kode dengan menggunakan plastik mika yang diberi nomor dan diikat. Setelah itu babi ditimbang satu persatu dengan menggunakan timbangan duduk. Fungsi penimbangan babi disini adalah untuk mencari rataan bobot dari babi pada tiap perlakuan, kemudian setelah diperoleh rataan bobot maka pemilihan babi yang akan dipotong dilakukan dengan cara mencari selisih bobot yang sama pada tiap perlakuan. Selanjutnya babi dipotong dengan diawali penusukan leher (sticking) untuk mengeluarkan darah (bleeding). Penusukan leher dilakukan tepat di ujung depan tulang dada (Manubrium sterni dari Os sternum), dibagian ventral dan medium sehingga mengenai Arteri carotis, Vena jugularis dan vena cava cranialis.

Proses selanjutnya adalah pemanasan (scalding) dan pelepasan bulu (scurfing). Proses ini dilakukan dengan kompor pembakar selama \pm 5 menit yang diikuti dengan pengerokan bulu dan kulit ari dengan menggunakan pisau. Babi dibersihkan dengan menggunakan air dingin untuk menghilangkan sisasisa darah dan kotoran lainnya yang masih melekat. Proses selanjutnya adalah proses pengeluaran organ dalam yang terdapat di rongga perut (Cacum abdomen) dengan rongga dada (Cavum thoracis) dengan cara mengarah bagian ventral adbomen di medium dimulai dari pusar kedepan sampai ujung belakang ruas tulang dada yang paling belakang (Cartilago xiphoideus) dan belakang sampai tepi depan Os pubis, sehingga rongga dada dan rongga perut terbuka. Kaki bawah bagian depan dan belakang di potong masing-masing pada Articulatio carpo metacarpeae dan Articulatio atlanto occipitalis. Kepala dipisahkan dari badan pada Articulatio atlanto occipitalis yaitu pertemuan ruas tulang leher pertama (Atlas) dengan tulang kepala bagian belakang (Os occipitale) tetapi daging pipi ( $M$. masseter) masih melekat pada karkas. Sehingga yang dimaksud karkas disini adalah bagian hasil pemotongan setelah bagian-bagian seperti kepala, kaki bawah depan dan belakang dan semua organ dalam.

Karkas ditimbang dan selanjutnya dibelah menjadi dua bagian simetris (separuh kiri dan kanan) sepanjang ruas tulang belakang di median dari Os sacrum melewati Symphysis pelvis terus ke depan di tengahtengah tulang dada (Os sternum) dan sampai ke ruas tulang leher. Karkas direcah menjadi enam bagian yang meliputi: ham, loin, boston, picnic, jowl, dan baconbelly (National Live Stock and Meat Board, 1973 dikutip Soeparno, 2009). Kemudian recahan karkas tersebut ditimbang untuk mengetahui beratnya.

\section{Analisis Data}

Data hasil penelitian dianalisis dengan sidik ragam. Apabila terdapat hasil yang berbeda nyata $(\mathrm{P}<0,05)$ maka dilanjutkan dengan uji jarak berganda Duncan pada taraf 5\% (Steel dan Torrie, 1991).

\section{HASIL DAN PEMBAHASAN}

\section{Karakteristik Karkas Babi}

Hasil penelitian menunjukkan bahwa bobot potong babi bali jantan yang diberi ransum tanpa ampas pati aren sebagai kontrol (A) adalah $37,97 \mathrm{~kg}$ (Tabel 3) sedangkan babi bali yang diberi ransum kontrol dengan penggunaan $5 \%$ ampas pati aren (B), ransum kontrol penggunaan 10\% ampas pati aren (C) dan ransum kontrol penggunaan $15 \%$ ampas pati aren (D) dibandingkan dengan ransum A menghasilkan bobot potong lebih rendah yaitu masing-masing $0,66 \%, 2,55 \%$ dan $4,11 \%$ secara statistik berbeda tidak nyata $(\mathrm{P}>0,05)$. 
Hal ini disebabkan konsumsi protein yang mengalami penurunan dan selain itu kandungan energi ransum juga mengalami penurunan. Protein merupakan zat makanan yang paling penting bagi tubuh yang berfungsi sebagai zat pembangun, pengatur dan sebagai bahan bakar dalam tubuh, selain itu pula banyaknya protein dalam ransum sangat berpengaruh terhadap pencapaian bobot badan ternak.

Malheiros et al. (2003) menyatakan bahwa semakin rendah protein di dalam suatu bahan pakan ataupun ransum mengakibatkan pertumbuhan dan konsumsi pakan menjadi rendah dibandingkan dengan kandungan protein yang sedang maupun lebih tinggi. Lebih lanjut Astuti et al. (2009) menyatakan tinggi kandungan protein kasar dalam ransum maka palatabilitas dan pakan juga akan meningkat.

Tabel 3. Penggunaan ampas pati aren dalam ransum terhadap karakteristik karkas babi bali jantan

\begin{tabular}{lccccc}
\hline \multirow{2}{*}{\multicolumn{1}{c}{ Variabel }} & \multicolumn{5}{c}{ Perlakuan ${ }^{1)}$} \\
\cline { 2 - 5 } & A & B & C & D & \\
\hline Bobot potong (kg) & $\left.37,97^{\mathrm{a} 2}\right)$ & $37,72^{\mathrm{a}}$ & $37,00^{\mathrm{a}}$ & $36,41^{\mathrm{a}}$ & 0,85 \\
Bobot karkas (kg) & $24,86^{\mathrm{a}}$ & $24,45^{\mathrm{a}}$ & $24,00^{\mathrm{a}}$ & $23,50^{\mathrm{a}}$ & 0,50 \\
Panjang karkas (cm) & $73,53^{\mathrm{a}}$ & $73,04^{\mathrm{a}}$ & $72,98^{\mathrm{a}}$ & $72,54^{\mathrm{a}}$ & 1,20 \\
Persentase karkas (\%) & $65,58^{\mathrm{a}}$ & $64,96^{\mathrm{a}}$ & $64,94^{\mathrm{a}}$ & $64,52^{\mathrm{a}}$ & 1,64 \\
Tebal lemak punggung & $3,46^{\mathrm{a}}$ & $3,26^{\mathrm{a}}$ & $3,10^{\mathrm{a}}$ & $3,01^{\mathrm{a}}$ & 0,26 \\
(cm) & & & & & \\
Luas UDMR (cm ${ }^{2}$ ) & $55,63^{\mathrm{a}}$ & $53,84^{\mathrm{a}}$ & $54,04^{\mathrm{a}}$ & $53,36^{\mathrm{a}}$ & 1,26 \\
FI & $0,34^{\mathrm{a}}$ & $0,33^{\mathrm{a}}$ & $0,33^{\mathrm{a}}$ & $0,32^{\mathrm{a}}$ & 0,01 \\
\hline
\end{tabular}

Keterangan :

1) A : Ransum kontrol tanpa ampas pati aren; $B$ : Ransum kontrol dengan penggunaan $5 \%$ ampas pati aren; $C$ : Ransum kontrol dengan penggunaan $10 \%$ ampas pati aren; D : Ransum kontrol dengan penggunaan $15 \%$ ampas pati aren

2) Superkrip yang sama pada baris yang sama menunjukan perbedaan yang tidak nyata $(P>0,05)$ dan superkrip yang berbeda pada baris yang sama menunjukan perbedaan yang nyata $(P<0,05)$

3) SEM : Standard Error of the Treatment Means

Hasil penelitian menunjukkan bobot karkas babi yang diberi perlakuan A yaitu 24,86 kg (Tabel 3) sedangkan perlakuan B, C dan D masing-masing 1,65\%, $3,46 \%$, dan $5,47 \%$ lebih rendah dibandingkan dengan perlakuan A, namun secara statistik berbeda tidak nyata $(\mathrm{P}>0,05)$. Hal ini dipengaruhi oleh bobot potong pada perlakuan A lebih tinggi daripada perlakuan lainnya. Semakin tinggi bobot potong seekor ternak akan menghasilkan bobot karkas yang tinggi pula. Menurut Budaarsa (1997) babi yang mempunyai bobot badan yang tinggi apabila dipotong akan menghasilkan persentase karkas yang tinggi pula. Soeparno (2005) mengatakan karkas babi merupakan bobot seekor babi yang telah dipotong setelah dikurangi atau dipisahkan bagian kepala, paru-paru, jantung, jeroan dan ke empat kaki mulai dari korpus (lutut bagian depan) dan tarsus (lutut bagian belakang).

Hasil penelitian menunjukkan bahwa persentase karkas babi yang diberikan perlakuan A sebesar 65,58\%
(Tabel 3). Persentase karkas pada perlakuan B, C, dan D masing-masing sebesar 0,95\%; 0,98\%; dan 1,62\% lebih rendah dibandingkan dengan perlakuan A namun secara statistik berbeda tidak nyata $(\mathrm{P}>0,05)$. Persentase karkas merupakan hasil pengukuran dari bobot potong (bobot hidup) dan bobot karkas, karena presentase karkas merupakan perbandingan antara bobot karkas dengan bobot hidup saat di potong yang dikurangi saluran pencernaan dan urine dan dikalikan dengan 100\%. Tingginya persentase karkas pada perlakuan A disebabkan oleh bobot potong pada perlakuan tersebut juga paling tinggi dari perlakuan lainnya. Soeparno (1992) menyatakan bahwa bobot potong yang semakin tinggi menghasilkan karkas yang semakin tinggi pula sehingga diharapkan bagian pertumbuhan daging menjadi lebih besar.

Karkas yang baik merupakan karkas yang lebih banyak bagian dagingnya dari pada bagian tulang dan lemak (Seputra, 2004). Persentase karkas pada penelitian ini sesuai dengan pendapat Sinaga (2012) yang menyatakan karkas babi berkisar antara 60-75\% dari bobot hidupnya dan persentase karkas babi adalah lebih tinggi dibandingkan dengan domba dan sapi atau ternak lainnya. Hal ini disebabkan oleh tubuh babi memiliki rongga yang lebih kecil serta mempunyai lambung tunggal sehingga ruang untuk pembentukan daging menjadi lebih besar. Dikatakan pula bahwa bobot karkas dari ternak babi dipengaruhi oleh faktor internal yaitu genetik serta faktor eksternal atau luar seperti lingkungan, manajemen pemeliharaan, dan pakan (Sriyani et al., 2017).

Hasil penelitian menunjukkan panjang karkas babi pada perlakuan A adalah $73,53 \mathrm{~cm}$ (Tabel 3). Panjang karkas pada perlakuan B, C, dan D dibandingkan dengan perlakuan A memiliki panjang karkas yang lebih kecil masing-masing 0,61\%, o,75\% dan 1,35\% dan secara stastistik berbeda tidak nyata $(\mathrm{P}>0,05)$. Panjang karkas babi erat kaitannya dengan bobot potong. Babi yang memiliki bobot potong yang tinggi cenderung akan memiliki panjang karkas lebih tinggi dari pada babi yang memiliki bobot badan yang rendah. Selain itu panjang karkas juga dipengaruhi oleh pertumbuhan tulang, terutama tulang belakang. Seputra (2004) dalam penelitiannya babi yang diberi ransum limbah tempe dari taraf $5 \%, 10 \%$ dan $15 \%$ babi P2 pemberian $5 \%$ limbah tempe memiliki panjang karkas yang lebih tinggi dari pada $\mathrm{P}_{1}, \mathrm{P}_{3}$, dan $\mathrm{P}_{4}$ hal tersebut disebabkan bobot potong pada perlakuan P2 paling tinggi. Budaarsa (1997) menyatakan panjang karkas lebih dipengaruhi oleh tumbuhnya ruas tulang belakang (Columna vertebralis) yang berbeda antara batas depan rusuk pertama dan tulang pangkal paha belakang. Jaringan ini bertumbuh dini, sehingga ukuran liniernya lebih sulit dipengaruhi oleh perlakuan pakan atau lainnya 
selama pertumbuhan.

Hasil penelitian menunjukkan tebal lemak punggung yang diberi perlakuan A adalah $3,46 \mathrm{~cm}$ (Tabel 3). Tebal lemak punggung pada perlakuan B, $\mathrm{C}$ dan $\mathrm{D}$ lebih rendah masing-masing 5,78\%, 10,48\% dan $13,00 \%$ dibandingkan dengan perlakua $\mathrm{A}$, namun secara statistik berbeda tidak nyata $(\mathrm{P}>0,05)$. Tingginya tebal lemak punggung pada perlakuan A disebabkan oleh bobot potong yang tinggi pada perlakuan A. Tebal lemak punggung merupakan salah satu penilaian kualitas karkas babi yang dipengaruhi oleh tipe babi, umur, ransum, bobot hidup dan kastrasi (Fabbricate dan Sutan, 1980). Gurmilang (2003) menyatakan ternak yang memiliki bobot potong yang minimum akan menghasilkan tebal lemak punggung yang lebih rendah dibandingkan dengan ternak yang memiliki bobot potong maksimum. Tebal lemak punggung juga berkaitan dengan ternak babi pada perlakuan A yang diberi kandungan protein, energi dan lemak yang tinggi dari pada perlakuan lainnya (Tabel 2). Kelebihan lemak akan disimpan didalam hati dalam bentuk glikogen atau diubah menjadi lemak yang disimpan di bawah kulit (subkutan), lemak internal (lemak disekitar perut, rongga dan ginjal) dan lemak intramuscular (lemak marbling). Terjadinya penurunan tebal lemak punggung pada perlakuan penggunaan ampas pati aren dalam ransum sebagai sumber serat karena ampas pati aren mampu mengikat lemak untuk diekskresikan bersamaan dengan feses. Wilfart et al. (2007) menyatakan meningkatnya konsentrasi serat dalam ransum menyebabkan meningkatnya kandungan ekstrak ether feses ternak babi.

Hasil penelitian menunjukkan luas urat daging mata rusuk (loin eye area) yang diberi perlakuan A sebesar $55,63 \mathrm{~cm}^{2}$ (Tabel 3). Luas UDMR pada perlakuan B, $\mathrm{C}$ dan $\mathrm{D}$ lebih rendah masing-masing 3,21\%, 2,85\%, dan 4,08\% dibandingkan dengan perlakuan A dan secara stastistik berbeda tidak nyata $(\mathrm{P}>0,05)$. Luas urat daging mata rusuk (UDMR) atau loin merupakan salah satu indikator jumlah daging (perototan) karkas yang sangat penting karena merupakan petunjuk dari muscling (perototan). Semakin luas UDMR, persentase daging biasanya meningkat dan peringkat karkas semakin baik. Luas UDMR pada perlakuan A lebih luas dari pada perlakuan lainya. Hal ini disebabkan oleh bobot potong yang tinggi pada perlakuan A sehingga menghasilkan berat karkas yang tinggi pula. Sejalan dengan pendapat Soeparno (2009) bahwa luas urat daging mata rusuk juga dipengaruhi oleh bobot potong.

Hasil penelitian menunjukkan fleshing index yang diberi perlakuan A sebesar $0,34 \mathrm{~cm} / \mathrm{kg}$ (Tabel 3). Fleshing index pada perlakuan B, C dan D lebih rendah masing-masing 2,94\%, 2,94\% dan 5,88\% dibandingkan dengan perlakuan A dan secara stastistik berbeda tidak nyata $(\mathrm{P}>0,05)$. Fleshing index merupakan perbandingan antara berat karkas dengan panjang karkas (Santosa 1995). Semakin tinggi bobot karkas persatuan panjangnya, maka semakin baik konformasi karkas yang dihasilkan sehingga jumlah daging karkas yang dihasilkan semakin banyak. Dalam penelitian ini bobot karkas perlakuan A merupakan yang paling tinggi sehingga nilai flesing index pada perlakuan tersebut paling tinggi dari pada perlakuan lainnya.

Hasil penelitian menunjukkan persentase daging karkas yang diberikan perlakuan A sebesar 45,05\% (Tabel 4). Persentase daging pada perlakuan B, C dan $\mathrm{D}$ lebih rendah masing-masing $0,51 \%, 1,43 \%$ dan $1,86 \%$ dibandingkan dengan perlakuan A namun secara statistik berbeda tidak nyata $(\mathrm{P}>0,05)$. Tingginya persentase daging karkas pada perlakuan A disebabkan oleh tingginya bobot potong pada perlakuan A (Tabel 5.1). Soeparno (1998) menyatakan bahwa ada hubungan yang erat antara bobot karkas dan bagian-bagian karkas dengan bobot potong, sehingga apabila hasil analisa bobot potong dan bobot karkas diperoleh hasil tidak signifikan maka hasilnya juga tidak berpengaruh pada bagian-bagian karkas.

Tabel 4. Penggunaan ampas pati aren dalam ransum terhadap komposisi karkas babi bali jantan

\begin{tabular}{lccccc}
\hline \multirow{2}{*}{ Variabel } & \multicolumn{4}{c}{ Perlakuan $^{1)}$} & \multirow{2}{*}{ SEM $^{3}$ ) } \\
\cline { 2 - 5 } & $\mathrm{A}$ & $\mathrm{B}$ & $\mathrm{C}$ & $\mathrm{D}$ & \\
\hline Daging (\%) & $\left.45,05^{\mathrm{a} 2}\right)$ & $44,82^{\mathrm{a}}$ & $44,40^{\mathrm{a}}$ & $44,21^{\mathrm{a}}$ & 0,40 \\
Tulang (\%) & $14,75^{\mathrm{a}}$ & $15,21^{\mathrm{a}}$ & $16,57^{\mathrm{b}}$ & $17,26^{\mathrm{c}}$ & 0,20 \\
Lemak (\%) & $40,22^{\mathrm{b}}$ & $39,98^{\mathrm{b}}$ & $39,03^{\mathrm{ba}}$ & $38,48^{\mathrm{a}}$ & 0,39 \\
\hline
\end{tabular}

Keterangan :
1) A : Ransum kontrol tanpa ampas pati aren; $\mathrm{B}$ : Ransum kontrol dengan penggunaan $5 \%$ ampas pati aren; C : Ransum kontrol dengan penggunaan $10 \%$ ampas pati aren D : Ransum kontrol dengan penggunaan $15 \%$ ampas pati aren

2) Superkrip yang sama pada baris yang sama menunjukan perbedaan yang tidak nyata $(P>0,05)$ dan superkrip yang berbeda pada baris yang sama menunjukan perbedaan yang nyata $(P<0,05)$

3) SEM : Standard Error of the Treatment Means

Hasil penelitian menunjukkan persentase tulang karkas pada perlakuan A sebesar 14,75\% (Tabel 4). Sedangkan persentase tulang pada perlakuan B sebesar $3,13 \%$ lebih tinggi dibandingkan dengan perlakuan A dan secara stastistik berbeda tidak nyata $(\mathrm{P}>0,05)$. Sedangkan perlakuan C dan D masing-masing $12,39 \%$ dan 17,07\% juga lebih tinggi dibandingkan dengan perlakuan A, secara stastistik berbeda nyata $(\mathrm{P}<0,05)$. Persentase tulang tertinggi dihasilkan oleh perlakuan D yaitu 17,26\% kemudian berturut-turut diikuti oleh perlakuan C, B dan A yaitu 16,57\%, 15,21\% dan 14,75\% (Tabel 4). Tulang merupakan bagian yang tumbuh secara biologi dan penting akan tetapi kurang bernilai ekonomi apabila dibandingkan dengan bagian karkas lainnya. Persentase tulang pada perlakuan D merupakan paling tinggi hal ini berkaitan dengan proporsi komponen daging karkas lebih kecil pada perlakuan D. Menurut 
Soeparno (2009) bila proporsi dari salah satu komponen karkas lebih tinggi maka proporsi dari salah satu atau kedua komponen lainnya akan menjadi lebih rendah atau sebaliknya. Budaarsa et al. (2007) menyatakan dalam proses pembentukan tulang karkas terdapat dua mineral yang paling dominan dalam pembentukan tulang yaitu mineral kalsium dan fosfor. selain itu tulang merupakan jaringan yang tumbuh paling awal karena tulang merupakan jaringan vital dibandingkan jaringan otot dan lemak sehingga merupakan prioritas nutrien paling tinggi.

Hasil penelitian menunjukan persentase lemak karkas pada perlakuan A sebesar 40,22\% (Tabel 4). Sedangkan persentase pada perlakuan B, C dan D lebih rendah masing-masing 0,59\%, 2,95\% dan 4,31\% dibandingkan dengan perlakua A dan secara stastistik berbeda nyata $(\mathrm{P}<0,05)$. Persentase lemak tertinggi dihasilkan oleh perlakuan A yaitu 40,22\% kemudian berturut-turut diikuti oleh perlakuan B, C dan D yaitu 39,98\%, 39,03 dan 38,48 (Tabel 4). Tingginya persentase lemak pada ternak babi yang diberi perlakuan A karena kecernaan energi dan protein kasar yang paling tinggi pada perlakuan A, sehingga konsumsi energi yang tinggi mampu menghasilkan bobot potong yang tinggi pula pada perlakuan A (Tabel 3). Selain itu pula kandungan energi pada ransum A merupakan paling tinggi daripada perlakuan lainnya. Pakan dengan kandungan energi yang tinggi yang dikonsumsi oleh ternak dapat menghasilkan deposit lemak dalam tubuh yang tinggi. Hal ini sesuai dengan Ariana dan Suranjaya (2016) yang menyatakan lemak karkas yang tinggi merupakan hasil dari ransum yang berenergi tinggi. Lemak tubuh berasal dari lemak ransum (lemak eksogenus) dan lemak yang disintesa dalam tubuh (endogenus). Menurut Soeparno (2009) proporsi lemak karkas yang tinggi sebagai akibat dari perlakuan pakan yang berenergi tinggi.

Terjadinya penurunan kadar lemak pada perlakuan $\mathrm{B}, \mathrm{C}$ dan $\mathrm{D}$ disinyalir dengan meningkatnya konsumsi ransum disetiap perlakuan sehingga menyebabkan konsumsi serat kasar menjadi meningkat. Dimana serat berfungsi utnuk mengganggu enzim-enzim yang ada di saluran pencernaan, mengganggu pembentukan misel, mengganggu kandungan isi usus dan menghambat biosintesis kolesterol. Dengan demikian pemberian serat berpengaruh bukan saja terhadap kolesterol tetapi juga terhadap penimbunan lemak tubuh (Stipanuk 2000). Lebih lanjut Poendjiadi (2005) menyatakan serat kasar yang berasal dari pakan setelah dikonsumsi akan mengikat asam empedu sesampainya di saluran pencernaan, sehingga menyebabkan fungsi empedu untuk membantu penyerapan lemak akan terhambat. Selanjutnya asam empedu yang sudah terikat oleh serat kasar akan dikeluarkan dari tubuh dalam bentuk feses sehingga mengakibatkan penurunan deposisi lemak.

\section{SIMPULAN}

Berdasarkan hasil penelitian penggunaan ampas pati aren dalam ransum ternak babi, maka dapat disimpulkan bahwa penggunaan ampas pati aren dari $5-15 \%$ dalam ransum babi bali jantan, tidak mempengaruhi karakteristik karkas yaitu berat karkas, persentase karkas, luas urat daging mata rusuk, fleshing index dan persentase daging tetapi menurunkan persentase lemak karkas pada babi bali jantan.

\section{UCAPAN TERIMAKASIH}

Pada kesempatan ini penulis mengucapkan terimakasih kepada Bapak Dr. Ir. Ida Bagus Gaga Partama, MS. Selaku Dekan Fakultas Peternakan Universitas Udayana yang telah memberi fasilitas dan tempat penelitian kepada penulis sehingga penelitian dan penulisan artikel ini dapat terlaksana. Kepada ibu pembimbing pertama yaitu Dr. Ni Luh Putu Sriyani, S.Pt., MP dan bapak pembimbing kedua Prof. Dr. Ir. I Ketut Sumadi, MS. yang telah memberikan bimbingan selama penelitian dan penulisan serta terimakasih juga semua pihak yang membantu dengan ikhlas selama penelitian.

\section{DAFTAR PUSTAKA}

Ariana, I N.T, dan I G. Suranjaya. 2016. Kualitas kimia daging sapi bali yang diberi pakan sampah kota. Udayana Serving Journal. Vol 15 No 3.

Aritonang, D. 1993. Babi, Perencanaan dan Pengolahan Usaha Babi. Penerbit PT. Penebar Swadaya, Jakarta.

Astuti, Dewi, Arif, dan Andang. 2009. Pengaruh Konsentrasi Susu Skim dan Waktu Fermentasi terhadap Hasil Pembuatan Soyghurt. Jurnal Ilmiah Teknik Lingkungan. Vol. 1. No 2.

Budaarsa, K. 1997. Kajian Penggunaan Rumput Laut dan Sekam Padi Sebagai Sumber Serat dalam Ransum untuk Menurunkan Kadar Lemak Karkas dan Kolesterol Daging Babi. Disertasi. Program Pascasarjana Institut Pertanian Bogor.

Budaarsa, K., P. H. Siagian, dan Kartiarso. 2007. Penggunaan Rumput Laut dan Sekam Sebagai Sumber Serat Dalam Ransum Terhadap Kadar Lemak Karkas Babi. Jurnal Ilmu Ternak, Desember 2007, Vol. 7 No. 2, 95-100.

Fabbricate, T. and W.J. Sutan. 1980. Practical Meat Cutting and Merchandising Vol. 2. Pork, Lamb, Veal. The Avi Publishing Company Inc. Westport.

Firdayati, M. dan Handayani, M, 2005. Studi Karakteristik Dasar Limbah Tepung Aren, Jurnal Infrastruktur dan Lingkungan Binaan, Vol.I No. 2.

Gurmilang, A. A. 2003. Pengaruh taraf zeolit dan tepung darah sebagai sumber protein dalam ransum terhadap 
kualitas karkas babi. Skripsi. Fakultas Peternakan, Institut Pertanian Bogor, Bogor.

Hasnnudi. 2005. Kajian Tumbuh Kembang Karkas dan Komponennya serta Penampilan domba Sungei Putih dan Lokal Sumatera yang Menggunakan Pakan Limbah Kelapa Sawit. Sekolah Pascasarjanan, Institut Pertanian Bogor.

http://www.damandiri.or.id/detail.php? id=255. (20 Januari 2017).

Malheiros, R. D., M.B. Moraes, A. Collin, P.J. Janssens, E. Decuypere, and J. Buyse. 2003. Dietary Macronutrients, Endocrine Functioning and Intermediary Metabolism in Broiler Chickens. Nutr. Res., 23:567- 578.

Poendjiadi, A. 2005. Dasar-dasar biokimia. UI Press. Jakarta.

Santosa, U. 1995. Tata Laksana Pemeliharaan Ternak. PT. Penebar Swadaya, Jakarta.

Seputra, I M. A. 2004. Penampilan dan Kualitas Karkas Babi Landrace yang diberi Ransum Mengandung Limbah Tempe. Tesis. Fakultas Peternakan. Universitas Udayana, Bali.

Siagian, P. H. 1999. Manajemen Ternak Babi. Fakultas Peternakan Institut Pertanian Bogor. Bogor.

Sikka S S. 2007. Effect of replacement of maize and rice bran with paddy on the growth performance and carcass traits of growing finishing pigs. http://www.cipav.org. co/lrrd19/7/sikk19092.htm[30 july 2017].
Sinaga, S. 2012. Tips Pemeliharaan Ternak Daerah atau Musim Panas. http: //blogs.unpad.ac.id/ saulandSinaga/?cat=1. Dikunjungi 20 Okt 2017.

Soeparno. 2009. Ilmu dan Teknologi Daging. Yogyakarta : Gadjah Mada University Press.

Soeparno. 1992. Ilmu dan Teknologi Daging. Gajah Mada University Press. Yogyakarta.

Soeparno. 1998. Ilmu dan Teknologi Daging. Cetakan ketiga. Gadjah Mada University Press, Yogyakarta.

Soeparno. 2005. Ilmu dan Teknologi Daging, Cetakan III. Gadjah Mada University Press. Yogyakarta.

Sriyani, N. L P., Rasna M. A., Ariana I N. A., dan Puger A.W. 2017. Profil Asam Lemak Daging Babi Bali Asli dan Babi Landrace. Majalah Ilmu Peternakan. Vol 20. 12-15. Fakultas Peternakan Univ. Udayana.

Steel, R. G. D dan J. H. Torrie. 1991. Prinsip dan Prosedur Stastistika Suatu Pendekatan Biometrik (Terjemah: Bambang Sumatri). Jakarta: PT. Gramedia.

Stell, R.G.D dan J.H. Torrie. 1991. Prinsip dan Prosedur Stastistika Suatu Pendekatan Biometrik (Terjemah: Bambang Sumatri). Jakarta: PT. Gramedia.

Stipanuk, M. H. 200o. Biochemical and Physiologic Aspect of Human Nutrition. Philadelphia: Saunders Company.

Wilfart, A., L. Montagne, P. H. Simmins, J. van Milgen, and J. Noblet. 2007. Sites of nutrient digestion in growing pigs: effect of dietary fiber. J. Anim. Sci. 85: 976-983. 